\title{
The Prediction of Curcumin Content in the Turmeric Rhizome with Raman Handheld Spectroscopy
}

\author{
I Made A. G. Wirasuta ${ }^{1 *}$, Cokorda I. T. R. Dewi ${ }^{1}$, Ni Putu L. Laksmiani ${ }^{1}$, I Gusti A. M. \\ Srinadi ${ }^{2}$, Deddi P. Putra ${ }^{3}$ \\ ${ }^{1}$ Pharmacy Department, Faculty of Mathematic and Natural Science, Udayana University, \\ Bali, Indonesia \\ ${ }^{2}$ Mathematic Department, Faculty of Mathematic and Natural Science, Udayana University, \\ Bali Indonesia \\ ${ }^{3}$ Faculty of Pharmacy, Andalas University, Padang, Indonesia
}

\begin{abstract}
Submitted 07 April 2018; Revised 21 May 2018; Accepted 23 May 2018; Published 01 October 2018
*Corresponding author: gelgel.wirasuta@unud.ac.id
\end{abstract}

\begin{abstract}
The quality control of herbal medicine should be started from the determination of the active substance at harvest time. The Raman spectrometry has been used for this propose. The aim of this study is to determine the quantification of curcumin in turmeric rhizome (Curcuma longa Linn.) using Raman spectroscopy combined with multivariate analysis of PLSR that are expected to provide reference method for quality control in turmeric rhizome, especially for raw materials of Herbal drugs. Parameters that can be used for analysis of curcumin levels on turmeric rhizome obtained using intensity Raman signal and the data obtained from the standard method will be processed with multivariate analysis methods PLSR. The validation value of quantification result using Raman-PLSR is seen from $\mathrm{R}^{2}$ value of 0.957 , RMSEC value of 0.199 and p-value of 0.00 . The study showed the developed method could be implemented on to determine the prediction quantification of raw material herbal medicine.
\end{abstract}

Keywords: Curcumin, PLS-R, Raman spectroscopy, turmeric.

\section{Prediksi Kandungan Kurkumin dalam Rimpang Kunyit dengan Spektroskopi Handheld Raman}

\begin{abstract}
Abstrak
Kontrol kualitas tanaman obat seharusnya dimulai dari penetapan kandungan bioaktif saat panen. Spektrofotometri Raman sangat dimungkinkan untuk digunakan untuk kebutuhan ini. Tujuan dari penelitian ini adalah menentukan kandungan kurkumin dalam rimpang kunyit menggunakan spektrofotometri Raman menggunakan analisis multivariate PLSR, dimana metode dapat diterapkan pada kontrol kualitas bahan baku rimpang kunyit. Parameter yang digunakan dalam analisis PLS-R adalah intensitas spectrum Raman dan data yang diperoleh dari metode standar. Hasil validasi RamanPLSR ditentukan oleh nilai $\mathrm{R}^{2}$ : 0,957, nilai RMSEC: 0,199, dan nilai $\mathrm{p}$ sebesar 0,00 . Studi menunjukkan metode yang dikembangkan dapat diterapkan untuk memprediksi kandungan kurkumin dalam rimpang kunyit.
\end{abstract}

Kata Kunci: , Kunyit, kurkumin, PLS-R, spektroskopi Raman. 


\section{Introduction}

Raman scattering spectroscopy employs to detect vibrations in molecules. The Raman spectrum is used to identify substances from the characteristic spectral fingerprint, and to determine the quantitative information about compositions of samples. The Raman analytical application technique promises a non-destructive and non-invasive of sample preparation method, which is often desirable to characterize the pharmaceutical preparation and bulk chemical constituency the sample. ${ }^{1,2}$

The Handheld Raman spectroscopy is a portable and battery operated instrument, which provide hands-on lab analysis in the field quality control of chemical materials. ${ }^{3}$ Herbal medicine standardization is an analytical procedure or a system that ensures the substance amount of quantity, quality and therapeutic effect of active ingredients in each dose. The analytical method should provide the phytochemical fingerprint, which utilizes the authenticity and quality control of raw material and the preparations. ${ }^{4}$ The Raman spectrum offers qualitative and quantitative information of the measured substances. The handheld Raman could be used for field quality control of curcumin contain in the turmeric rhizome. ${ }^{5,6}$

The multivariate Partial Least SquareRegression (PLS-R) has been implemented to predict and determinate the curcumin content in the turmeric rhizome of quantitative information of measured substance IRspectrum. ${ }^{7}$ Curcumin contain in rhizome determinate by HPLC or TLC on the other hand The Raman spectra of the same samples measured. This study aimed to provide simple and non-destructive analytical method, which could implement in field quality control of curcumin content in the turmeric rhizome samples using portable Raman spectroscopy.

\section{Materials and Methods}

\subsection{Chemicals and materials}

All chemicals used in this study were analytical grade. The solvents were methanol and chloroform (Merck-Germany), TLC is GF 254 (Merck-Germany). Curcumin standard was prepared by Faculty of Pharmacy Andalas University- Indonesia. The turmeric rhizomes were collected from three difference places in Bali. The equipment used in the study included glassware (IWAKI-PyrexIndonesia), twin trough chamber $20 \times 10$ cm (Camag-Switzerland), semiautomatic TLC sampler (Camag-Switzerland), TLC Scanner 4 and winCATS software (CamagSwitzerland), analytical balance (ANDJapan), moister analyzer balance (ShimadzuJapan), Oven, and Rigaku Raman Handheld (Rigaku-USA).

\subsection{Sample preparation and Raman measurement}

Turmeric rhizome was cleaned from the soil with water, then cupped and dried in the oven at $60^{\circ} \mathrm{C}$ until the water content in between $10-11 \%(\mathrm{w} / \mathrm{w})$. The dried rhizome was divided into six groups. Each group was powdered and then placed into the vial. The each powdered turmeric rhizomes were measured their Raman spectrum. Raman measurements were performed using a Rigaku's FirstGuard 1064 nm spectrometer. The single-mode laser light was at $1064 \mathrm{~nm}$;

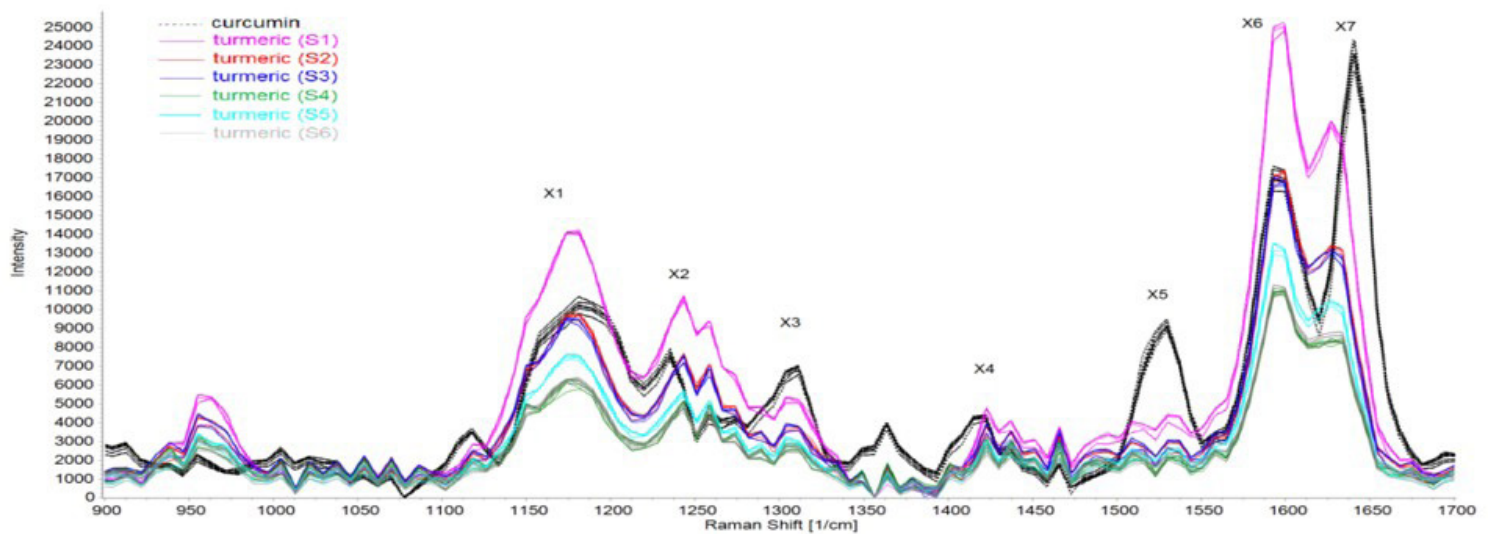

Figure 1. Raman spectra of curcumin and turmeric rhizome 
the laser power was adjusted to approximately $100 \mathrm{mV}$, the exposer time measurement was $2000 \mathrm{~ms}$. The spectral range was from 200 - $2000 \mathrm{~cm}-1$. Each sample was scanned in six times. All data was collected using software $21 \mathrm{CRF}$ part 11 . The SpectraGraph 1.0 - spectroscopy software (Dr F. Menges, Germany) was used for import/export data of Rigaku's file format into ASCII-XY.

\subsection{Quantification of curcuminoid}

The curcumin content in turmeric rhizome was determined with TLCdensitometry. The powdered rhizomes were extracted with methanol. The $10 \mu \mathrm{L}$ extract was spotted on plat TLC, and the standard curcumin concentration was ranged between 25, 50, 100, 150, 200 and $250 \mathrm{ng} / \mathrm{spot}$. The spotted extract and reference where eluted in twin chamber with mobile phase chloroform: methanol $(95: 5, \mathrm{v} / \mathrm{v})$. Each curcumin spot was scanned $426 \mathrm{~nm}$.

\subsection{Chemometric analysis}

The Raman spectra peaks were identified based on a functional group of curcumin. The identified peaks were used to predict the curcumin content of turmeric rhizomes. The peak intensity was collected with the help of the spectrograph 1.0. These peak intensities of curcumin datasets were analyzed using multivariate calibration of partial least square regression (PLS-R) was performed with Minitab 17 statistical software. A "Leave One Out Cross Validation" validation procedure was applied to result in the $\mathrm{R}^{2}$ value, and RMSEC (Root Mean Square Error of Calibration), RMSEP (Root Mean Square
Error of Prediction), and the process variation coefficient (Vxo) as a relative prediction precision. ${ }^{6,8}$ The valid calibration model was used to predict the curcumin content in the turmeric rhizome.

\section{Results}

Turmeric rhizome presented three chromatogram peaks, and the peaks with Rfvalue of 0.63 showed identical $R f$-value and in-situ UV-Vis spectrum with the curcumin reference. All peaks presented the same in-situ UV-Vis spectrum as the curcumin spectrum.

Figure 1 presents the comparison Raman spectra between curcumin reference and turmeric rhizome. The Raman spectra of each sample were scanned six times repetitions, so totally was obtained 42 spectra. The clustering of those spectra with single linkage method was obtained the similarity between all spectra of $92.82 \%$. The principal component analysis (PCA) of all spectra recommended for one group with the similarity of $94.4 \%$.

The precision of the assigned peaks intensity of turmeric rhizome are present in table 1 and 2. The results of PLS-R model validations are presented in table 4 . The using of the better PLS-R model to predict curcuminoid content in different old of turmeric rhizome samples presents in the table 5 .

\section{Discussion}

The main compound contained in turmeric rhizome was curcuminoids, such as curcumin, demethoxycurcumin, and bis-desmethoxycurcumin. The Rf-value of curcumin was 0.63 . The other peaks with

Table 1. The mean and \%RSD of the curcumin assigned peaks intensity Raman Spectra of turmeric rhizome samples

\begin{tabular}{cccccccc}
\hline \multirow{2}{*}{ Sample } & \multicolumn{7}{c}{ mean (\%RSD), n=6 } \\
\cline { 2 - 8 } & $\mathrm{X}_{1182}$ & $\mathrm{X}_{1235}$ & $\mathrm{X}_{1311}$ & $\mathrm{X}_{1422}$ & $\mathrm{X}_{1530}$ & $\mathrm{X}_{1599}$ & $\mathrm{X}_{1641}$ \\
\hline S1 & $14090.8(0.6)$ & $9200.2(0.6)$ & $4923.2(2.1)$ & $4495.8(3.5)$ & $4139.0(4.5)$ & $25017.7(0.7)$ & $13503.5(1.0)$ \\
S2 & $9685.3(1.6)$ & $6331.3(1.3)$ & $3557.0(2.7)$ & $3523.3(6.5)$ & $2707.2(5.2)$ & $17271.0(0.8)$ & $10083.3(1.3)$ \\
S3 & $9373.8(1.6)$ & $6293.8(1.0)$ & $3534.2(2.9)$ & $3671.5(6.5)$ & $2795.0(6.2)$ & $16737.3(0.7)$ & $8902.0(1.6)$ \\
S4 & $6067.0(3.0)$ & $4092.3(2.9)$ & $2562.7(5.9)$ & $2836.5(7.8)$ & $1981.3(2.9)$ & $12803.8(0.9)$ & $5855.2(0.9)$ \\
S5 & $7485.7(1.5)$ & $4791.5(1.1)$ & $2760.8(3.8)$ & $2781.5(6.9)$ & $2379.0(5.3)$ & $12466.3(1.0)$ & $7038.2(1.3)$ \\
S6 & $6219.0(2.1)$ & $4060.2(1.8)$ & $2477.2(4.7)$ & $2573.5(8.1)$ & $2123.3(6.6)$ & $11065.8(1.1)$ & $6127.2(2.4)$ \\
\hline
\end{tabular}


Table 2. The mean and \%RSD of the intensity of the rhizome assigned peaks intensity Raman Spectra of turmeric rhizome samples

\begin{tabular}{cccccccc}
\hline \multirow{2}{*}{ Sample } & \multicolumn{7}{c}{ mean (\%RSD), $\mathrm{n}=6$} \\
\cline { 2 - 8 } & $\mathrm{X}_{1174}$ & $\mathrm{X}_{1243}$ & $\mathrm{X}_{1305}$ & $\mathrm{X}_{1423}$ & $\mathrm{X}_{1530}$ & $\mathrm{X}_{1599}$ & $\mathrm{X}_{1627}$ \\
\hline S1 & $14077.7(0.2)$ & $10613.8(1.2)$ & $5223.3(2.4)$ & $4465.0(3.2)$ & $4257.0(4.1)$ & $25017.7(0.7)$ & $19872.5(0.7)$ \\
S2 & $9627.2(0.9)$ & $7545.3(2.1)$ & $3768.7(3.5)$ & $3473.2(6.2)$ & $2820.5(4.6)$ & $17271.0(0.7)$ & $14460.0(0.5)$ \\
S3 & $9475.3(0.6)$ & $7404.0(2.3)$ & $3774.0(4.4)$ & $3578.0(5.9)$ & $2918.2(5.7)$ & $16737.3(0.9)$ & $13104.7(0.6)$ \\
S4 & $6088.3(3.6)$ & $5002.7(3.6)$ & $2764.5(6.7)$ & $2738.8(7.6)$ & $2106.0(3.0)$ & $12803.8(0.9)$ & $8267.3(1.5)$ \\
S5 & $7523.5(1.4)$ & $5575.7(2.3)$ & $3038.3(5.7)$ & $2714.2(6.3)$ & $2467.7(4.8)$ & $12466.3(1.0)$ & $10390.5(0.9)$ \\
S6 & $6262.5(1.0)$ & $4877.3(3.4)$ & $2658.5(6.5)$ & $2503.0(7.8)$ & $2227.2(5.9)$ & $11065.8(1.1)$ & $8606.7(1.5)$ \\
\hline
\end{tabular}

Rf-value of 0.50 and 0.45 possessed in-situ UV-Vis spectrum similar to curcumin. So it is possible belong to other curcuminoid (such as demethoxycurcumin and bisdesmethoxycurcumin. The separation of curcuminoids with same system was provided by Revathy et al. 2011., 90 The curcumin present Rf-value at 0.75 , demethoxycurcumin at 0.55 and bis-desmethoxycurcumin at 0.27. Based on the polarity of curcuminoids and the comparison data preseted by Revathy could be pressumed, that the peak with Rf-value of 0.45 was provided by the highest polar substance, such bis-desmethoxycurcumin but the middle peak with Rf-value of 0.5 is owned by demethoxycurcumin.

The first step for prediction curcuminoid content of turmeric rhizome using Raman Handheld spectroscopy combined with multivariate calibration PLS-R is peak selection of wavenumbers region. The peak of spectra was labeled with $11 \%$ threshold and 2\% prominence. The height at $963 \mathrm{~cm}^{-1}$ corresponds to vibration $v(\mathrm{C}=\mathrm{O})$ stretching, peak at $1422-1423 \mathrm{~cm}^{-1}$ corresponds to $\mathrm{O}-\mathrm{CH}_{3}$ deformation vibration,
$\mathrm{CH}_{2}$ scissoring vibration, symmetric $\mathrm{COO}$ stretching, and $\mathrm{CH}$ deformation. The peak at $1530 \mathrm{~cm}^{-1}$ is characteristic of aromatic $\mathrm{C}=\mathrm{C}$ stretching vibration. The peak at $1599 \mathrm{~cm}^{-1}$ is characteristic of $\mathrm{C}=\mathrm{C}$ stretching and at 1627 $1641 \mathrm{~cm}^{-1}$ corresponds to $\mathrm{C}=\mathrm{O}$ stretching. The peaks of X6 and X7 could be assigned to the benzene ring1. The wavenumbers of assigned peaks both curcumin and turmeric rhizomes showed in Fig. 1. These peaks intensities were used to predict curcumin content in the turmeric sample.

The peaks of X1, X2, X6, and X7 possessed the $\%$ RSD value less than $2 \%$, but all the $\%$ RSD values of the peaks intensity of $\mathrm{X} 3, \mathrm{X} 4$, and $\mathrm{X} 5$ were more than $2 \%$. The peaks shifting measurement introduced a variation in their intensity at the assigned peaks

The turmeric rhizome contained curcumin, demethoxycurcumin, and bisdesmethoxycurcumin. These contents alleged to be responsible for the impairment similarity. The Raman was unable to distinguish the difference in its curcuminoid contents; therefore its curcuminoid was determinate as curcumin total.

Table 3. Curcuminoid contains $(\%, \mathrm{~m} / \mathrm{m})$ of turmeric rhizome determined by TLC densitometry.

\begin{tabular}{cccc}
\hline & & \multicolumn{2}{c}{$\begin{array}{c}\text { The predicted values } \\
{[\%, w / w(\% \text { wSD })]}\end{array}$} \\
\cline { 3 - 4 } Sample & $\begin{array}{c}\text { The actual contain } \\
{[\%, \mathrm{w} / \mathrm{w}]}\end{array}$ & Curcumin peaks & Rhizome peaks \\
\hline S1 & 3.38 & $3.42(2.72)$ & $3.38(1.83)$ \\
S2 & 2.56 & $2.58(3.00)$ & $2.38(2.69)$ \\
S3 & 2.37 & $2.20(2.83)$ & $1.65(3.27)$ \\
S4 & 1.37 & $1.59(9.73)$ & $1.87(2.87)$ \\
S5 & 1.47 & $1.60(5.56)$ & $1.63(4.18)$ \\
S6 & 2.14 & $1.90(7.99)$ & \\
\hline
\end{tabular}


Table 4. The validation parameters of PLS-R model.

\begin{tabular}{ccc}
\hline Peaks Assignment & Curcumin & Turmeric Rhizome \\
\hline RMSEC & 0.199 & 0.307 \\
RMSEP & 0.265 & 0.322 \\
R $^{2}$ & 0.957 & 0.895 \\
Vxо (\%) & 8.740 & 12.578 \\
\hline
\end{tabular}

The lower RMSEC and RMSEP values and the higher $\mathrm{R}^{2}$-value indicated a better of PLS-Remodel. The prediction of curcuminoid content based on the curcumin assigned peaks provided lower prediction precision $\left(\mathrm{V}_{\mathrm{xo}}\right)$ value then based on the turmeric rhizome assigned peaks. The PLS-R model based on the curcumin assigned peaks is a good model for prediction of curcuminoid content in turmeric rhizome sample. The using of the better PLS-R model to predict curcuminoid content in different old of turmeric rhizome samples presents in table 5 .

\section{Conclusion}

The Raman Handheld spectrometry is suitable to use for prediction the curcuminoid content in turmeric rhizome without sample destruction. The PLS-R based on the curcumin assigned peaks introduced a better PLS-R model with lower prediction error.

\section{Reference}

1. Buckleya K, Matouseka P. Recent advances in the application of transmission Raman spectroscopy to pharmaceutical analysis. Journal of Pharmaceutical and Biomedical Analysis. 2011; 55: 645-652

2. Peng Q, Zeng C, Zhou Y, Lian S, Nie G. Rapid Determination of Turmeric Roots Quality Based on the Raman Spectrum of Curcumin. Food Anal. Methods. 2015; 8 (1): $103-108$.

3. Wirasuta IMAG, Arimbawa I.BS, Yudiastra IK, Rashid MAPP, Purnama IGPP, Winarti NW, Laksmiani NPL. Optimasi Pembacaan Spektrum Raman Portabel Untuk Pembacaan Spektrum Raman Preparathistologi Jaringan BPH (Benign Prostate Hyperplasia). Jurnal Farmasi Udayana. 2016; 5(2):1-6.

4. Wirasuta IMAG, Srinadi IGAM,
Table 5. The predicted curcuminoid content in age of rhizome variation.

\begin{tabular}{ccc}
\hline \multirow{2}{*}{$\begin{array}{c}\text { Age of Rhizome } \\
\text { (month) }\end{array}$} & \multicolumn{2}{c}{ Curcuminoid content $(\%, \mathrm{~m} / \mathrm{m})$} \\
\cline { 2 - 3 } & Mean & $\%$ RSD \\
\hline 2 & 5.47 & 2.87 \\
6 & 9.70 & 2.07 \\
10 & 13.48 & 1.47 \\
\hline
\end{tabular}

Dwidasmara IBG, Ardiyanti NLPP, Trisnadewi IGAA, Paramita NLPV. Authentication of Piper Betle L folium and quantufucation of theri antifungalcativitty. Journal of Traditional and Complementaru Medicine. 2017; 7 (3): 288-295

5. Baranska M, Schulz H, Rosch P, Strehlec MA, Popp J. Identification of secondary metabolites in medicinal and spice plants by NIR-FT-Raman microspectroscopic mapping. Analyst. 2004; 129: 926 - 930

6. Rohman A, Sudjadi, Devi D, Ramadhani A, Nugroho. Analysis of Curcumin in Curcuma longa and Curcuma zanthorriza Using FTIR Spectroscopy and Chemometrics. Research Journal of Medicinal Plant. 2015; 9 (4): 176-186.

7. Broa R, Rinnana A, Faber NKM. Standard error of prediction for multilinear PLS 2. Practical implementation in fluorescence spectroscopy. Chemometrics and Intelligent Laboratory Systems. 2005; 75 : 69- 76.

8. Funk W, Dammann V, Donnevert G. Quality assurance in analytical chemistry. Wiley-VCH Verlag GmbH \& Co. KGaA, Weinheim. 2007; p 23-60.

9. Revathy S, Elumalai S, Benny M, Antony B. Isolation Purification and Identification of Curcuminoids from Turmeric (Curcuma longa L.) by Column Chromatography. Journal of Experimental Sciences. 2011; 2(7): 21-25.

10. Mangolim CS, Moriwaki C, Nogueira AC, Sato F, Baesso ML, Neto AC, Matioli G. Curcumin-b-cyclodextrin inclusion complex: Stability, solubility, characterisation by FT-IR, FT-Raman, $\mathrm{X}$-ray diffraction and photoacoustic spectroscopy, and food application. Food Chemistry. 2014; 153: 361-370. 